\title{
Industry 4.0-Related Digital Divide in Enterprises: An Analysis for The European Union-28
}

Hayriye ATIK (https://orcid.org/0000-0001-7480-080X), Department of Economics, Erciyes University, Turkey; e-mail: atik@erciyes.edu.tr

Fatma ÜNL Ü (https://orcid.org/0000-0003-1822-9965), Department of Economics, Erciyes University, Turkey; e-mail:funlu@erciyes.edu.tr

\section{İşletmelerde Endüstri 4.0 ile İlgili Dijital Bölünme: Avrupa Birliği-28 Ülkeleri Üzerine Bir Analiz}

\begin{abstract}
Digital divide has been measured using various indicators in the literature so far. In contrast from the literature, this paper addresses the digital divide within European Union member states according to Industry 4.0-related indicators that have been used for the first time in empirical literature. While Finland, the UK and Germany are among the countries with economic development levels above the EU average, Cyprus, Bulgaria, and Romania are among the countries that are below the Union average in terms of Industry 4.0-related development. It is clear that an Industry 4.0-related digital divide is observable within EU member countries. The European Union should try to decrease the digital gap between member countries by developing and supporting special Industry 4.0 policies, especially for members below the EU average. Therefore, the results of this article will help policy makers in the EU and in member countries.
\end{abstract}

Keywords : Industry 4.0, Digital Divide, Digital Agenda, Digital Development, European Union, Factor Analysis.

JEL Classification Codes : $\quad$ C380, C390, O140, O330, O520, O570.

Öz

Dijital bölünme literatürde genellikle farklı göstergeler kullanılarak ölçülmektedir. Literatürden farklı olarak, bu çalışma Endüstri 4.0 göstergerlerine göre Avrupa Birliği'ne üye devletler arasındaki dijital bölünmeye işaret etmektedir. Finlandiya, İngiltere ve Almanya gibi AB ortalamasının üstünde ekonomik gelişmişlik performansına sahip olan ülkeler Endüstri 4.0 açısından yüksek performansa sahipken; G. Kıbrıs, Bulgaristan ve Romanya gibi ülkeler AB ortalamasının altında performans sergilemiştir. $\mathrm{Bu}$ durum $\mathrm{AB}$ üyesi ülkelerde dijital bölünmenin açık bir şekilde gözlemlendiğini göstermektedir. AB ülkeleri özellikle ortalamanın altında değerlere sahip olan üye ülkeler için özel politikalar geliştirerek ve bu politikaları destekleyerek üye ülkeler arasındaki dijital açığı kapatmalıdır. Bu çalışmanın sonuçları AB'deki politikacılara ve üye ülkelere yol gösterecektir.

Anahtar Sözcükler $\quad$ : Endüstri 4.0, Dijital Bölünme, Dijtal Ajanda, Dijital Gelişme, Avrupa Birliği, Faktör Analizi. 


\section{Introduction}

From the past to the present, four industrial revolutions have taken place. The First Industrial Revolution mainly influenced the manufacturing sector via steam-powered mechanical equipment. The Second Industrial Revolution was characterised by the mass production of industrial products. The Third Industrial Revolution, which led to the information society, changed the world using electronics and information technology in production. The current era is considered the Fourth Industrial Revolution, which is characterised by the linking of sub-components in production processes via the Internet of Things (IoT).

The Fourth Industrial Revolution is generally known as Industry 4.0. The term Industry 4.0 was first used in Germany in 2011 as a proposal for the new concept of German economic policy. Smart industry, or Industry 4.0, refers to the technological evolution from embedded systems to Cyber Physical Systems (CPS). The concept takes into account the increased computerisation of manufacturing industries. Industry 4.0 contains the convergence and application of nine digital industrial technologies. These are advanced robotics, additive manufacturing, augmented reality, simulation, horizontal/vertical integration, industrial internet, cloud computing services (CCS), cyber security and Big Data, and Analytics.

If successfully implemented, the potential benefits of Industry 4.0 relate to productivity gains, revenue growth, and competitiveness (European Parliament, 2016). These benefits are very important for the European Union (EU) through its new industrial policy re-shaped by the Europe 2020 strategy, which emphasises smart, sustainable and inclusive growth as a way to overcome the structural weaknesses in Europe by improving its competitiveness and productivity (European Union, 2016).

In this context, the existence of Industry 4.0-related digital inequalities between EU member countries will threaten the success of its new industrial policy and 2020 strategy. The digital divide has been defined as "the gap between individuals, households, business and geographic areas at different socio-economic levels with regard both to their opportunities to access ICT and to their use of Internet for a wide variety of activities." (OECD, 2001).

The digital divide has been measured by several studies in the literature (Cruz-Jesus et al., 2012; Cuervo \& Menendez, 2006; Dewan et al., 2005; Cruz-Jesus et al., 2016). The earlier studies, except the study by Cruz-Jesus et al. (2016), generally measured the digital gap across countries. In contrast from the earlier studies, this paper focuses on measuring the Industry 4.0-related digital divide within EU members for the first time in the literature. This study differs from the others not only for the indicators used for digital divide, but also for the indicators chosen for Industry 4.0. Earlier studies to determine the performance of countries towards Industry 4.0 generally used data related to the information economy, such as research and development activities and ICT usage. However, this article differs from them by using Industry 4.0 indicators such as cloud computing, big data, mobile devices etc. 
The context of this study is the European Union, which recognises that developing a digital industry based on Industry 4.0-related indicators is a critical issue for the union's present and future competitiveness [1].The Digital Agenda for Europe, included in the 2020 strategy as the first of the seven strategy's flagships, aims to help Europe's businesses increase their competitiveness.

The goal of this paper is to address Industry 4.0-related digital divide within the EU. In particular, this paper addresses the following research questions: 1) What are the most important features of the Industry 4.0-related digital divide across the 28 member states of the European Union? 2) To what extent is there an Industry 4.0-related digital divide in the EU-28? The remainder of this paper is organised as follows: After the introduction, sections 2 and 3 present the theoretical background and literature review, respectively; section 4 describes the data; section 5 presents the methodology, analysis, and discussion of the results; section 6 draws some concluding results.

\section{Theoretical Background}

\subsection{Terminology}

As a result of the global implications of the new industrial revolution, many countries have started to establish associations to accelerate the development of industrial technologies. Different terms are being used to define this new development by Germany and the US as the leading countries in the current revolution. The term Industry 4.0 was first introduced by the Industry-Science Research Alliance as a future project of the High- Tech Strategy of the German Federal Government. "Platform Industrie 4.0" is the most popular initiative, which includes German politicians, unions, and scientists to accelerate this transformation (Roland Berger, 2014).

The terms "Industrial Internet of Things (IIoT)", "Advanced Manufacturing (AM)", "Smart Manufacturing (SM)", "Re-industrialisation (RI)", and Internet of Things "(IoT)" have been widely used in the US. IoT was first used by General Electric in 2012 (Platform Industrie 4.0, 2013). Leading Industry players such as AT\&T, General Electric and IBM founded the Industrial Internet Consortium (IIC). Its aim was to promote the adoption and the use of "Industrial Internet" technologies.

Japan used the term "Industrial Intelligence," which describes the situation in which industrial objects will become smart when they are connected to the internet. The phrase "Made Different - factories of the future" is widely used in Belgium, while the term "Smart Industries" is used in the Netherlands.

\subsection{Key Features}

Industry 4.0 has had important influence on the transformation of industry as a result of the following three advancements (Alamada-Lobo, 2015; Schlechtendahl et al., 2015):

- The digitalisation of production and information systems, 
- The automation of systems,

- Automatic data interchange.

Digitalisation of production and information systems is a necessary development for the management and planning of production. Obtaining data from the production line needs the automation of systems. Automatic data interchange helps link manufacturing sites in a supply chain.

Industry 4.0 has four main components. These are CPS, the IoT, the loS, and the smart factory (Greengard, 2015).

\section{Cyber Physical Systems (CPS)}

Recently, the term Cyber Physical Systems (CPS) has surfaced in place of the term embedded systems. Embedded systems are information systems embedded into physical devices. These systems are found in telecommunications, automation, and transport systems. However, a well-known definition of CPS is that they are integrations of computation, networking, and physical processing (Gilchrist, 2016). Accordingly, even a human operator is considered a CPS. A human operator has physical and cyber components. The operator may communicate with other operators and with the system, as well as interact through mechanical interfaces. An intelligent production line is also an example of CPS. A machine can perform many tasks by communicating with its components and with the product (Lom et al., 2016).

CPS is closely related to big data. This is because CPS generates large amounts of data, which is referred to as big data, to improve system scalability, security, and efficiency (Xu \& Duan, 2019). Big data is defined as "a bound that subtly connects and integrates the physical world, the human society, and cyberspace" (Jin et al., 2015).

\section{The Internet of Things (IoT)}

The IoT is a network of physical products to collect and sense data from the world, and then share that data through the internet where it can be processed for various purposes. In a simple definition, the IoT is of relevance if any device or even a living being is connected to the internet (Roblek et al., 2016).

The IoT is also called the Internet of Everything or the Industrial Internet, which is a new technology paradigm envisioned as a global network of machines and devices capable of interacting with each other. The IoT is recognized as one of the most important areas of future technology.

Currently, the internet connects more than a billion people through computers, tablets, and smartphones. However, in the future, people will be linked through small devices which will connect (through wireless) to the internet (Lee \& Lee, 2015). 
The IoT and cloud computing have become two very closely affiliated future internet technologies, with one providing the platform for the other's success. Cloud computing refers to storing and accessing data and programs over the internet instead of on one's computer hard drive. Cloud computing services (CCS) have become a powerful architecture to perform large scale computing tasks. The necessity of storing, processing and analysing large amounts of data has motivated many enterprises to adopt cloud computing.

The IoT uses a variety of information-sensing identification devices and information processing equipment such as radio frequency identifiers (RFID). RFID is the use of radio waves to read and capture information stored on a tag attached to an object. An RFID system is made up of two parts: a tag (label) and a reader. To read the information encoded on a tag, a two-way radio receiver called an interrogator transmits a signal to the tag using an antenna. The tag responds with the information written in its memory bank. Finally, the interrogator transmits the read results to an RFID computer program. It is argued that industry 4.0 "will only work, if machines can communicate via CPS and commodity flows are tracked by RFID" through the parts of industry (Brettel et al., 2014).

The IoT is used in the following areas (Roblek et al., 2016):

- Smart infrastructure: Smart devices can improve flexibility, reliability, and efficiency in building infrastructure. For example, Apple has developed an application for homes, which allows control over door locks from any internetconnected source (Baunsgaard \& Clegg, 2015).

- Health care: Because hospital errors are still an important cause of preventable death, health care is another area which uses the IoT. Sensors are integrated with smartphones to monitor patients and send their information to doctors (Gilchrist, 2016).

- Supply chains/logistics: The information provided by the IoT may improve the efficiency of supply chains and logistics. This system develops a demand-driven model that reduces inventory and replenishes material based on sensing parts.

- Security and privacy: The transmission of data through wireless connections should be secure. Additionally, unauthorised access should not be allowed.

\section{The Internet of Services (IoS)}

Any device connected to the internet is expected of having service. These smart services are known as the IoS. These services, such as inventory control, logistics, and smart transportation will increase efficiency and reduce costs. However, in order to take advantages of the IoS, companies require structural changes.

\section{Smart Factory}

Sometimes the terms smart manufacturing, intelligent factory, and factory of the future are used instead of smart factory. A smart factory is one that is more intelligent, flexible, and dynamic. In these factories, the manufacturing process will be augmented by 
sensors and actors. This equipment will have the ability to improve the manufacturing process through self-optimization and autonomous decision making.

For today's smart factories, Enterprise Resource Planning (ERP) and Customer Relationship Management (CRM) are basic systems that perform the job. ERP is general standard integrated business and economic software, with which it is possible to perform business activities such as finance, manufacturing, and logistics. ERP systems have been accepted as the backbone of Industry 4.0 (Haddara \& Elregal, 2015).

CRM may be defined as a strategy of management and communication with customers aimed at collecting their information for the purpose of increasing customer satisfaction and therefore fostering better, longer and more profitable relationships with them. Personalized products for known customers are produced in Industry 4.0 with the help of robotics and programmable machines. CRM applications ensure the fulfilment of customer needs and increase customer satisfaction in Industry 4.0 (Dukic et al., 2017). When social media is integrated with CRM, a new communication channel will be established, and most of this communication will be between machines in the new era as they receive data through wireless sensors and send it to the smart service/product providers' centres (Roblek et al., 2016).

Industry 4.0 is based on six principles which support firms in putting Industry 4.0 into practice (Lom et al., 2016):

- Interoperability: This is the ability of CPS, in which Industry 4.0 factories and humans can communicate with each other through the IoT and Internet of Services (loS).

- Virtualisation: This explains that CPS can monitor physical processes.

- Decentralisation: The CPS in Industry 4.0 factories can make their own decisions. This process is called decentralisation.

- Real Time Capability: This is the ability to collect and analyse data immediately without stopping production in the case of the failure of the any machine. Thus, the factory will react quickly to the failure of any production machine.

- Service Orientation: This is the ability of services that can be offered to companies and other participants who need them. Services of companies, CPS, and people who can provide services are available over the IoS.

- Modularity: This explains the adaption of Industry 4.0 factories to changing requirements. Modular factories can easily be adapted to seasonal changes in demand.

\section{Literature Review}

The literature related to the performance of EU countries regarding Industry 4.0 can be divided into two categories. While the first group of studies concentrates on single European countries, the second group examines the EU as a whole. The first study which included some European countries was conducted by Infosys-a multinational corporation 
that provides business consulting, information technology, and outsourcing services in North America, Europe, India and internationally-and by the Institute for Industrial Management at the University of Aachen in Germany. More than 400 companies in China, France, Germany, the United Kingdom, and the United States were analysed in this survey. The results of the survey indicated that China was the leading innovator and had the highest level of penetration (INFOSYS, 2015). Basl (2016) surveyed Industry 4.0 trends in selected Polish and Czech companies through seven questions. The important fact from the survey was that only $18 \%$ of the Polish companies and $9 \%$ of the Czech companies were aware of the term Industry 4.0. More recently, Basl (2017) surveyed Industry 4.0-related developments in some Czech companies selected from the automotive, engineering, furniture, electric motor manufacturing and plastics sectors, as well as statistics and consulting services. The information compiled from the research indicates that Czech companies have a high awareness of Industry 4.0. However, $56 \%$ of the companies have stated that their employees are not aware of Industry 4.0.

Roland Berger Strategy Consultants (2015) conducted a survey to understand the role of Switzerland within the European manufacturing revolution. The survey results indicated that Switzerland did not lose industrial value added over the past decade and defended its share $(19 \%)$ of industrial value added in its total economy.

Some indices have also been suggested to measure the readiness of countries and regions regarding Industry 4.0. Ronald Berger Strategy Consultants (2014) developed an Industry 4.0 Readiness Index and ranked European countries using two sets of indicators: the industrial excellence indicator and the value network indicator. Production process sophistication, degree of automation, workforce readiness and innovation intensity constitute the industrial excellence indicator. The value network indicator consists of high value added, industry openness, innovation network and internet sophistication. The index showed that industrial European economies can be roughly divided into four categories: the frontrunners, the traditionalists, the hesitators, and the potentialists. The frontrunners (Sweden, Austria, Finland, Germany, and Ireland) have a large industrial base and have very modern technologies. Eastern European countries (the Czech Republic, Slovakia, Slovenia, Hungary, and Lithuania) are classified as traditionalists. While some Eastern European members have tried to develop their industrial structure, some have launched initiatives to put industry into the next era. Spain, Italy, Estonia, Portugal, Poland, Croatia, and Bulgaria were grouped in the hesitators. The specific characteristic of these countries is that they have a lack of reliable industrial base. Belgium, Denmark, the Netherlands, the UK, and France are accepted as potentialists. The main characteristic of these countries is that their industrial bases have been weakening for the last few years.

Another index was suggested by Nick \& Pongrácz (2016) to measure the relative readiness of cities. Known as the Smart Collaboration Index, it is based on two main dimensions. While the first dimension is related to performance indicators versus enablement indicators, the second dimension is related to the indicators by players and their performance such as industrial, regulatory and economic environments, and academy. They 
also suggest evaluating each group in terms of prerequisites, management, smarter systems, and outcomes.

Kuruczleki et al. (2016) determined the readiness of the European Union to embrace the Fourth Industrial Revolution by developing a readiness index consisting of eight indicators. Cluster analysis performed using readiness index values indicated that EU countries can be divided into four groups in transition to Industry 4.0.

Bittighofer et al. (2018) used the survey method to investigate the readiness level of German and French companies in terms of Industry 4.0 indicators. The survey results indicated that there is large potential for German companies to achieve a higher readiness level.

\section{Data}

Consistent with our theoretical framework, we measured the use of Industry 4.0related indicators within enterprises in the EU-28 using eleven variables. The data for these variables were extracted from Eurostat, Digital Economy and Society Statistics pertaining to the year 2016. The first variable is the percentage of enterprises buying CCS used over the internet. Hashem et al. (2015) examined cloud computing applications in the new era through well-known organizations such as SwiftKey, redBus, Nokia, and Alacer. Opportunities and advances in cloud computing in Industry 4.0 were explored by Marston et al. (2011) through a business perspective.

The percentage of enterprises using radio frequency identification (RFID) instruments is another variable used in empirical analysis. The applications and challenges of RFID technology for Industry 4.0 has been widely discussed by Jia et al. (2012). The percentage of enterprises giving portable devices for a mobile connection to the internet (Mobile) is the third variable included in the analysis. Mobile devices connected to the internet are important parts of enterprises in Industry 4.0. By using these devices, the capability of receiving, generating, and processing large amounts of information will be easier for enterprises in Industry 4.0.

Five variables used in the empirical work are related to big data. The reason for choosing big data- related variables is that big data will play a virtual role in the Fourth Industrial Revolution (Kagermann \& Wahlster, 2013). Although the potential benefits received from the use of big data will differ from one sector to another, the information sector, finance and insurance sectors, and government sector will gain from the use of big data. According to McKinsey (2011), manufacturers could reduce product development and assembly costs by up to $50 \%$ and realize a reduction in working capital by up to $7 \%$ using big data. The first variable related to big data is the share of enterprises analysing big data from any data source (EntData).

Data generated from some internet applications and websites, such as Facebook, Twitter, Instagram, Linkedln, YouTube, Google and WorldPress is generally referred to as 
"social big data" (Bello-Orgaz et al., 2016). As social media has become the most relevant data source for big data in the era of Industry 4.0, most enterprises generate big data from social media. For this reason, the percentage of enterprises analyzing big data generated from social media (EntMedia) was included in the empirical analysis.

Other big data related indicators are the percentage of enterprises analysing big data from geolocation of portable devices (EntDev); enterprises analysing their own big data from smart devices or sensors (EntOwn); and enterprises analysing big data from other sources (EntOther). The reason for including these variables is that EU enterprises use different ways of analysing big data.

The last three variables are related to software solutions like ERP and CRM. One of these variables is the percentage of enterprises using software solutions like CRM. While the abbreviation "CRM" was used for this variable in empirical work, the abbreviation "Market" was used for the percentage of enterprises using software solutions, like CRM, to analyse information about clients for marketing purposes. The main difference between these two variables is that the second variable shows CRM solutions used only for marketing purposes. The last variable (ERP) represents the percentage of enterprises that have ERP software packages for sharing information between different functional areas. The role of ERP and CRM systems for Industry 4.0 was discussed by Stojkic et al. (2016). The readiness of enterprises' ERP systems for the factories of the future was also explored by Haddara \& Elregal, (2015). The results indicated that the ERP systems in the sample countries are ready for the factories of the future.

Table: 1

\section{Description of Variables}

\begin{tabular}{|l|l|}
\hline Code & Variable \\
\hline CCS & Enterprises buying cloud computing services used over the internet \\
\hline RFID & Enterprises using radio frequency identification (RFID) instrument \\
\hline Mobile & Enterprises giving portable devices for a mobile connection to the internet \\
\hline EntData & Enterprises analysing big data from any data source \\
\hline EntOwn & Enterprises analysing own big data from enterprise's smart devices or sensors \\
\hline EntDev & Enterprises analysing big data from geolocation of portable devices \\
\hline EntMedia & Enterprises analysing big data generated from social media \\
\hline EntOther & Enterprises analysing big data from other sources \\
\hline CRM & Enterprises using software solutions like Customer Relationship Management (CRM) \\
\hline Market & Enterprises using software solutions, like CRM to analyse information about clients for marketing purposes \\
\hline
\end{tabular}

The data (see Table 2) show noticeable imbalances in Industry 4.0 adoption and use of the EU-28 enterprises: in Romania only $7 \%$ of enterprises utilize CCS, while in Finland $57 \%$ of the enterprises do so, a more than eightfold difference. These same two countries are also at different ends of the spectrum in the use of RFID instruments, with values of $1 \%$ and $8 \%$, respectively. Slovakia also has the highest percentage with Finland in this indicator. The share of enterprises giving portable devices for a mobile connection to the internet (Mobile) ranges from $41 \%$ in Bulgaria to $94 \%$ in Finland, a difference of more than double. The share of enterprises analysing big data from any data source (EntData) is 3\% in Cyprus and $19 \%$ in Malta and the Netherlands. 
Table: 2

\section{Data and Descriptive Statistics of the Variables used in the Analysis}

\begin{tabular}{|c|c|c|c|c|c|c|c|c|c|c|c|}
\hline Country & CCS & RFID & Mobile & EntData & EntOwn & EntDev & EntMedia & EntOther & CRM & Market & ERP \\
\hline Belgium & 0.28 & 0.04 & 0.80 & 0.17 & 0.06 & 0.08 & 0.07 & 0.04 & 0.40 & 0.22 & 0.50 \\
\hline Bulgaria & 0.07 & 0.03 & 0.41 & 0.07 & 0.02 & 0.05 & 0.02 & 0.01 & 0.17 & 0.16 & 0.25 \\
\hline Czech Rep. & 0.18 & 0.04 & 0.77 & 0.09 & 0.04 & 0.05 & 0.02 & 0.02 & 0.20 & 0.16 & 0.30 \\
\hline Denmark & 0.42 & 0.03 & 0.92 & 0.12 & 0.05 & 0.04 & 0.06 & 0.04 & 0.34 & 0.24 & 0.47 \\
\hline Germany & 0.16 & 0.06 & 0.67 & 0.06 & 0.02 & 0.03 & 0.02 & 0.01 & 0.45 & 0.24 & 0.56 \\
\hline Estonia & 0.23 & 0.03 & 0.75 & 0.13 & 0.07 & 0.06 & 0.07 & 0.04 & 0.27 & 0.15 & 0.22 \\
\hline Ireland & 0.36 & 0.06 & 0.71 & 0.11 & 0.04 & 0.05 & 0.05 & 0.02 & 0.33 & 0.26 & 0.25 \\
\hline Greece & 0.09 & 0.02 & 0.48 & 0.11 & 0.03 & 0.07 & 0.05 & 0.04 & 0.22 & 0.13 & 0.37 \\
\hline Spain & 0.18 & 0.06 & 0.76 & 0.08 & 0.03 & 0.04 & 0.04 & 0.02 & 0.35 & 0.27 & 0.35 \\
\hline France & 0.17 & 0.02 & 0.72 & 0.11 & 0.03 & 0.07 & 0.04 & 0.01 & 0.32 & 0.15 & 0.39 \\
\hline Croatia & 0.23 & 0.07 & 0.83 & 0.09 & 0.03 & 0.03 & 0.05 & 0.05 & 0.22 & 0.12 & 0.29 \\
\hline Italy & 0.22 & 0.03 & 0.65 & 0.09 & 0.03 & 0.03 & 0.03 & 0.03 & 0.30 & 0.18 & 0.36 \\
\hline Cyprus & 0.15 & 0.03 & 0.60 & 0.03 & 0.02 & 0.01 & 0.01 & 0.01 & 0.39 & 0.22 & 0.43 \\
\hline Latvia & 0.08 & 0.03 & 0.66 & 0.11 & 0.04 & 0.05 & 0.05 & 0.02 & 0.18 & 0.10 & 0.16 \\
\hline Lithuania & 0.17 & 0.07 & 0.81 & 0.12 & 0.06 & 0.07 & 0.06 & 0.06 & 0.34 & 0.19 & 0.40 \\
\hline Luxembourg & 0.19 & 0.05 & 0.79 & 0.13 & 0.04 & 0.07 & 0.05 & 0.02 & 0.36 & 0.22 & 0.39 \\
\hline Hungary & 0.12 & 0.03 & 0.66 & 0.07 & 0.03 & 0.04 & 0.03 & 0.01 & 0.15 & 0.09 & 0.16 \\
\hline Malta & 0.28 & 0.07 & 0.73 & 0.19 & 0.08 & 0.06 & 0.12 & 0.05 & 0.28 & 0.22 & 0.30 \\
\hline Netherlands & 0.35 & 0.02 & 0.69 & 0.19 & 0.09 & 0.08 & 0.10 & 0.03 & 0.47 & 0.27 & 0.45 \\
\hline Austria & 0.17 & 0.06 & 0.76 & 0.11 & 0.04 & 0.05 & 0.05 & 0.02 & 0.44 & 0.29 & 0.41 \\
\hline Poland & 0.08 & 0.02 & 0.65 & 0.06 & 0.02 & 0.04 & 0.02 & 0.00 & 0.24 & 0.16 & 0.21 \\
\hline Portugal & 0.18 & 0.03 & 0.71 & 0.13 & 0.04 & 0.08 & 0.07 & 0.03 & 0.29 & 0.19 & 0.44 \\
\hline Romania & 0.07 & 0.01 & 0.43 & 0.11 & 0.03 & 0.08 & 0.04 & 0.02 & 0.20 & 0.14 & 0.22 \\
\hline Slovenia & 0.22 & 0.05 & 0.78 & 0.11 & 0.07 & 0.04 & 0.04 & 0.01 & 0.29 & 0.16 & 0.33 \\
\hline Slovakia & 0.18 & 0.08 & 0.74 & 0.11 & 0.04 & 0.05 & 0.04 & 0.03 & 0.22 & 0.16 & 0.30 \\
\hline Finland & 0.57 & 0.08 & 0.94 & 0.15 & 0.08 & 0.07 & 0.06 & 0.05 & 0.39 & 0.30 & 0.37 \\
\hline Sweden & 0.48 & 0.03 & 0.85 & 0.10 & 0.05 & 0.04 & 0.04 & 0.05 & 0.35 & 0.25 & 0.43 \\
\hline U.K. & 0.35 & 0.01 & 0.68 & 0.15 & 0.03 & 0.05 & 0.10 & 0.05 & 0.30 & 0.17 & 0.17 \\
\hline Minimum & 0.07 & 0.01 & 0.41 & 0.03 & 0.02 & 0.01 & 0.01 & 0.00 & 0.15 & 0.09 & 0.16 \\
\hline Maximum & 0.57 & 0.08 & 0.94 & 0.19 & 0.09 & 0.08 & 0.12 & 0.06 & 0.47 & 0.30 & 0.56 \\
\hline Average & 0.22 & 0.04 & 0.71 & 0.11 & 0.04 & 0.05 & 0.05 & 0.02 & 0.30 & 0.19 & 0.33 \\
\hline Std. Dev. & 0.12 & 0.02 & 0.12 & 0.03 & 0.01 & 0.01 & 0.02 & 0.01 & 0.08 & 0.05 & 0.10 \\
\hline
\end{tabular}

\section{Analysis}

\subsection{Methodologies}

Factor analysis and multidimensional scaling analysis were used in the empirical work. Factor analysis is a multivariate statistical method used to determine a small number of factors (new variables) which can be used to represent the relationship between the interrelated variables (Tryfos, 1997; Tucker \& MacCallum, 1997; Yong \& Pearce, 2013; Tabachnick \& Fidell, 2015; Vicente \& Lopez, 2011). This analysis was used to analyse the digital divide in a number of studies (Cuervo \& Menendez, 2006; Vicente \& Lopez, 2011; Cruz-Jesus et al., 2012; Cruz-Jesus et al., 2016). Basically, there are two types of factor analysis. These are exploratory factor analysis (EFA) and confirmatory factor analysis (CFA) (DeCoster, 1998; Taherdoost et al., 2014). If the researcher has no expectations of the number or nature of the factors, EFA is applied. CFA is applied to test the proposed theory or model by the researcher (Taherdoost et al., 2014). EFA was used in this analysis for lack of prior knowledge or expectations concerning the number of factors. The basic objectives of EFA are to determine the number of common factors influencing a set of measures, determine the strength of the relationship between each factor and each observed measure, and reduce the number of variables (DeCoster, 1998; Taher Doost et al., 2014). 
Factor analysis generally proceeds in three stages (Manly, 1986). In the first step, the correlation matrix for all variables is computed. Variables that do not appear to be related to other variables can be identified from the matrix and associated statistics. In the second step, factor extraction-the number of factors necessary to represent the data and the method for calculating them -must be determined. The third step, rotation, focuses on transforming the factors to make them more interpretable. Scores for each factor can also be computed.

The second analysis used in the empirical work is multidimensional scaling (MDS) analysis. MDS is a multivariate statistical method which helps determine the distances between objects by showing them in a less dimensional conceptual space in which the relations between them are not known (Weinberg, 1991; Cox \& Cox, 2011; Borg \& Groenen, 2005; Saeed et al., 2018). This method is used to determine the similarities and differences between objects by reducing the complex relationships between objects to a simpler and more understandable level (De Leeuw \& Heiser, 1982; Giguere, 2006; Jaworska \& Anastasova, 2009). There are two basic assumptions of multidimensional scaling analysis (Nakip, 2006): i) as MDS does not have any distribution, the distance between the objects is expressed by the distances (configuration); ii) the distances between objects are symmetric. This analysis was used to determine the comparative assessment of Industry 4.0 performance of EU-28 countries in terms of digital divide.

\subsection{Industry 4.0-Related Digital Divide Across EU-28}

The correlation structure of the input data is particularly important for the success of factor analysis (Manly, 1986; Hair et al., 1995). The correlation matrix is one of the most commonly used statistical techniques for determining the relationships between variables (DeCoster, 1998; Taherdoost et al., 2014).

The correlation matrix (see Table 3) shows that each variable has at least one absolute correlation coefficient of 0.50 with another variable. Although this correlation value is not especially high, it ensures that all variables measure the same phenomenon (Verma, 2013; Yong \& Pearce, 2013; De Leeuw \& Heiser, 1982). Additionally, some variables have notably high correlations. For example, the percentage of enterprises analysing big data from any data source (EntData) has a correlation of 0.91 with the percentage of enterprises analysing big data generated from social media (EntMedia). Similarly, the percentage of enterprises using software solutions like CRM has a correlation of 0.85 with the percentage of enterprises using software solutions like CRM to analyse information about clients for marketing purposes (Market). For all that, the percentage of enterprises analysing big data from any data source (EntData) has a correlation of 0.79 with the percentage of enterprises analysing their own big data from smart devices or sensors and a value of 0.72 with the percentage of enterprises analysing big data from geolocation of portable devices. In contrast, the percentage of enterprises using radio frequency identification instruments (RFID) has a correlation of 0.37 with the percentage of enterprises using software solutions, like CRM to analyse information about clients for marketing purposes (Market). 
Table: 3

Correlation Matrix

\begin{tabular}{|c|c|c|c|c|c|c|c|c|c|c|c|}
\hline & CCS & RFID & Mobile & EntData & EntOwn & EntDev & EntMedia & EntOther & CRM & Market & ERP \\
\hline $\mathrm{CCS}$ & 1 & 0.24 & $0.69^{* *}$ & $0.49^{* *}$ & $0.58^{* * *}$ & 0.07 & $0.45^{*}$ & $0.58^{* *}$ & $0.49^{* *}$ & $0.62^{* *}$ & 0.28 \\
\hline RFID & & 1 & $0.52^{* *}$ & 0.08 & 0.28 & -0.10 & 0.05 & 0.26 & 0.22 & $0.37^{*}$ & 0.20 \\
\hline Mobile & & & 1 & 0.32 & $0.51^{* * *}$ & -0.02 & 0.27 & $0.45^{* *}$ & $0.42^{* *}$ & $0.44^{* *}$ & 0.34 \\
\hline EntData & & & & 1 & $0.79^{* *}$ & $0.72^{* *}$ & $0.91^{* * *}$ & $0.59^{* *}$ & 0.26 & 0.26 & 0.10 \\
\hline EntOwn & & & & & 1 & $0.46^{*}$ & $0.68^{* * *}$ & $0.51^{* *}$ & 0.34 & 0.36 & 0.17 \\
\hline EntDev & & & & & & 1 & $0.53^{* * *}$ & 0.29 & 0.05 & 0.04 & 0.07 \\
\hline EntMedia & & & & & & & 1 & $0.65^{* *}$ & 0.23 & 0.22 & 0.00 \\
\hline EntOther & & & & & & & & 1 & 0.13 & 0.17 & 0.13 \\
\hline CRM & & & & & & & & & 1 & $0.85^{* *}$ & $0.76^{* *}$ \\
\hline Market & & & & & & & & & & 1 & $0.61^{* *}$ \\
\hline ERP & & & & & & & & & & & 1 \\
\hline
\end{tabular}

* Correlation is significant at the 0.05 level (2-tailed); ** Correlation is significant at the 0.01 level (2-tailed).

The results obtained from the correlation matrix showed that factor analysis was suitable. Further insight into the appropriateness of factor analysis was gained by using the Bartlett test of sphericity and the Kaiser-Mayer-Olkin (KMO) measure of sampling adequacy (Cuervo \& Menendez, 2006 and Cruz-Jesus et al., 2016). In other words, the reasons for applying the KMO test are to decide whether our data is suitable for factor analysis. The reason for performing Barlett's test is to determine whether the relationship between indicators is significant. KMO statistics should be greater than 0.50 and Bartlett's test should be significant (e.g. p<0.05). Null hypothesis (Ho) and the alternative hypothesis (H1) can be stated (Atik \& Ünlü, 2017): Ho: $\mathrm{R}=1$ (Correlation matrix is unit matrix; there is not any correlation between variables). Thus, factor analysis cannot be applied to this data set. $\mathrm{H} 1: \mathrm{R} \neq 1$ (Correlation matrix is not a unit matrix; correlation is available between variables). Therefore, factor analysis can be applied to this data set. Ho is rejected at $95 \%$ level as $\mathrm{p}=0.00<0.05$. According to the results, we can apply factor analysis as the KMO statistic is 0.60 and Bartlett's test is $(0.00<0.05)$ significant.

In the second stage of the analysis, the EFA has been performed to decide the number of factors that should be retained for further analysis. To decide the number of factors, three criteria are usually considered (Sharma, 1996; Verma, 2013): Eigenvalues (above 1), percentage of variance (variance explained above 70\%) and scree plot (three breaking points) criteria. All these results indicated the existence of three factors. Accordingly, the number of optimal factors was three. As shown in Table 4, the first factor explained $32 \%$ of total variance, the second factor explained $24 \%$ and the third factor explained $21 \%$, and together these three factors explained $77 \%$ of total variance. In order to measure the scale reliability of each factor, we calculated Cronbach's Alpha which is a measure of internal consistency of the factors (Tavakol \& Dennick, 2011). These values were calculated as 0.87 for factor $1 ; 0.86$ for factor 2 and 0.67 for factor 3 . This means that the internal consistency of each factor was high. 
Table: 4

\section{Results of Factor Analysis (Factor Loadings, Variance Explained and Cronbach} Alpha)

\begin{tabular}{|l|c|c|c|}
\hline Rotated factor model: Varimax & \multicolumn{2}{|c|}{ Factor 3} \\
\hline & Factor 1 & Factor 2 \\
\hline EntData & $\mathbf{0 . 9 6}$ & 0.12 & 0.12 \\
\hline EntMedia & $\mathbf{0 . 9 0}$ & 0.03 & -0.16 \\
\hline EntDev & $\mathbf{0 . 7 9}$ & 0.06 & 0.32 \\
\hline EntOwn & $\mathbf{0 . 7 4}$ & 0.19 & 0.52 \\
\hline EntOther & $\mathbf{0 . 6 2}$ & -0.04 & 0.17 \\
\hline CRM & 0.13 & $\mathbf{0 . 9 3}$ & 0.07 \\
\hline ERP & -0.00 & $\mathbf{0 . 8 7}$ & 0.32 \\
\hline Market & 0.12 & $\mathbf{0 . 8 4}$ & $\mathbf{0 . 8 1}$ \\
\hline Mobile & 0.18 & 0.28 & $\mathbf{0 . 7 4}$ \\
\hline RFID & -0.07 & 0.12 & $\mathbf{0 . 6 3}$ \\
\hline CCS & 0.40 & 0.37 & $21 \%$ \\
\hline Variance (\%) & $32 \%$ & $24 \%$ & $77 \%$ \\
\hline Variance Total & $32 \%$ & $56 \%$ & $87 \%$ \\
\hline Cronbach's Alpha & $87 \%$ & $86 \%$ & \\
\hline
\end{tabular}

In the third stage of the analysis, the factor loadings of all the variables was calculated using the varimax rotation. The varimax rotation is the most widely used rotation technique in factor analysis. According to Verma (2013) "It is an orthogonal rotation of the factor axes to maximize the variance of the squared loadings of a factor on all the variables in a factor matrix, which has the effect of relocating the original variables into extracted factor". After varimax rotation, each extracted factor will tend to have either large or small loadings of any particular variable. Thus, the researchers can easily identify each variable in one and only one factor. As shown in Table 4, the first dimension is related mostly to variables representing big data, which is one of the key elements of Industry 4.0 (Kagermann \& Wahlster, 2013; Atik \& Ünlü, 2018). The first dimension is determined by EntData (0.96); enterprises analysing big data generated from social media (0.90); EntDev (0.79); enterprises analysing their own big data from their smart devices or sensors (0.74); and enterprises analysing big data from other sources (0.62). The second dimension is determined by CRM (0.93); enterprises who have ERP (0.87); and Market (0.84). This dimension is related to the use of software solutions for enterprises to share information with customers, stakeholders, etc. The third dimension is determined by enterprises giving portable devices for a mobile connection to the internet (0.81); enterprises using RFID instruments (0.74); and enterprises buying CCS used over the internet (0.63). This dimension is related to the IoT and CCS, which are elements of Industry 4.0 (Gilchrist, 2016; Stock \& Seliger, 2016).

We applied multidimensional scaling (MDS) analysis to more clearly determine the similarities and differences between the countries. The goal of an MDS analysis is to find a spatial configuration of objects when all that is known is some measure of their general (dis)similarity (Wickelmaier, 2013). There are several steps in this analysis. Firstly, fitness index and stress values are considered primarily for reliability and validity tests. The fitness index R2, which is the measure of goodness-of-fit, is the square of the correlation index, and the model of the variables included in the model reveals the power of explanation. The R2 ranges from 0 to 1 and as it approaches 1, the description power of the model increases. If it is above 0.60, the model fits. The stress value, which is the Kruskal test statistic, measures the quality of the model and ranges from 0 to 1 . Kruskal (1964) suggests that a stress value 
of 0.1 is fair, while 0.05 is good, and anything 0.025 or below is excellent. Kruskal's stress is a badness-of-fit measure, in that values closer to zero are better (Kruskal, 1964; Jacoby \& Ciuk, 2014). As a result of multidimensional scaling analysis, the $\mathrm{R} 2$ value is 0.95 . This means that the variables included in the model have a high explanatory power $(0.95>0.60)$. Stress value indicating the quality of the model is calculated as 0.12 , which is fair. These results indicate that the analysis can proceed.

In the second stage of the MDS analysis, it is necessary to interpret the Euclidean distance model. In the multidimensional scaling analysis, where each object is represented by a point in a multidimensional space, the distances between objects are shown on the map. Two dimensions are generally preferred in the model and the first dimension is the y axis; the second dimension indicates the $\mathrm{x}$ axis. On the map, if the objects are particularly close to each other, they are similar, but if they are distant from each other, they are not similar. The similarity or difference between the objects can be determined by the Euclidean distance model. However, a distance matrix is needed to determine the distance between objects clearly in numerical terms. There is an inverse relationship between the objects and the values in this matrix; that is, the similarity of the objects with low values is high. The results of the multidimensional scaling analysis are shown in Table 5.

Table: 5

\section{Stimulus Coordinates}

\begin{tabular}{|c|c|c|}
\hline Countries & Dimension 1 & Dimension 2 \\
\hline Belgium & 1.24 & 0.66 \\
\hline Bulgaria & -2.33 & 0.33 \\
\hline Czech Republic & -0.39 & -0.62 \\
\hline Denmark & 1.98 & -0.25 \\
\hline Germany & 0.47 & 1.73 \\
\hline Estonia & -0.22 & -0.82 \\
\hline Ireland & 0.52 & -0.83 \\
\hline Greece & -1.60 & 0.77 \\
\hline Spain & 0.26 & 0.41 \\
\hline France & -0.10 & 0.43 \\
\hline Croatia & 0.03 & -0.99 \\
\hline Italy & -0.25 & 0.27 \\
\hline Cyprus & -0.32 & 1.25 \\
\hline Latvia & -1.57 & -0.73 \\
\hline Lithuania & 0.46 & 0.43 \\
\hline Luxembourg & 0.48 & 0.39 \\
\hline Hungary & -1.54 & -0.88 \\
\hline Malta & 0.30 & -0.63 \\
\hline Netherlands & 1.34 & 0.92 \\
\hline Austria & 0.63 & 0.97 \\
\hline Poland & -1.35 & -0.22 \\
\hline Portugal & 0.03 & 0.61 \\
\hline Romania & -2.24 & 0.19 \\
\hline Slovenia & 0.13 & -0.28 \\
\hline Slovakia & -0.41 & -0.43 \\
\hline Finland & 2.59 & -0.95 \\
\hline Sweden & 1.90 & -0.40 \\
\hline United Kingdom & -0.04 & -1.33 \\
\hline
\end{tabular}

According to the stimulus coordinate table, Bulgaria (-2.33) and Romania (-2.24) have values greater than -1 , meaning that these countries differ from other countries in terms of Industry 4.0 performance. Additionally, Greece (-1.60), Latvia (-1.57), Hungary (-1.54) and Poland (-1.35) are countries with values greater than -1 and have similar characteristics. 
Considering the countries that received values greater than +1 in the first dimension, it is seen that Finland (2.59) separated from the other countries. Similarly, Denmark (1.98), Belgium (1.24), Sweden (1.90) and the Netherlands (1.34) are countries that have values greater than +1 and have similar characteristics. In the second dimension, it is seen that England has a value greater than -1 (-1.33). Considering the countries with values of greater than +1 in the second dimension, it is observed that Germany (1.73) and Cyprus (1.25) were separated from the other countries. The figure, which is created according to the Stimulus coordinate table and called the Euclidean distance model, is given below in Figure 1.

Figure: 1

Stimulus Configuration (Euclidean Distance Model)

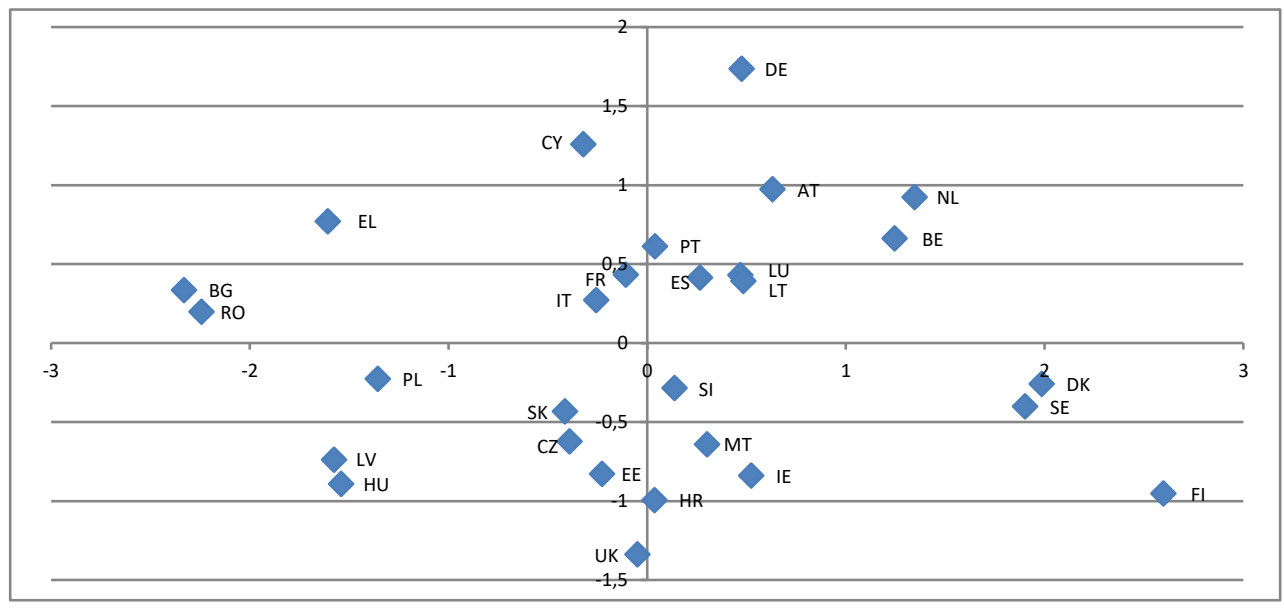

Figure 1 shows that EU-28 countries do not have similar characteristics in terms of Industry 4.0 performance and are located relatively far away from each other in the coordinate system. Therefore, the results of the analysis show that EU countries do not exhibit a homogenous appearance in this respect. Conversely, considering the relationship between the level of development of these countries and the performance of Industry 4.0, it can be concluded that countries with similar levels of economic development are located close to each other in the coordinate system (e.g. Bulgaria and Romania; Denmark and Sweden; the Netherlands and Belgium; France and Italy; Slovakia and the Czech Republic). According to the findings of the multidimensional scaling analysis, Bulgaria, Romania, Finland, the UK, Germany, and Cyprus have different performance levels in terms of Industry 4.0 from the other EU countries included in the analysis. Finland, the UK, and Germany are among the countries with economic development levels above the EU average, while Cyprus, Bulgaria and Romania are among those that are below the average. Even though the remaining countries' results are in parallel with their relative economic development, it can be said that the union is generally heterogeneous. 


\section{Conclusion}

This paper has analysed the digital divide across the EU-28 using Industry 4.0 indicators for the year 2016. While earlier studies have generally focused on information society-related indicators in measuring digital divide, this study has focused on using Industry 4.0-related indicators for this measurement. In the literature, instead of the countries' Industry 4.0 performance, the countries' or enterprises' Industry 4.0 readiness has been determined using information society statistics. For the first time in the literature, the Industry 4.0 performance of the countries was measured through Industry 4.0 indicators selected from the literature.

Despite our best efforts to develop a complete and multidimensional analysis between the EU countries, some limitations should be emphasised. Firstly, our empirical work consists of eleven variables, and some features of Industry 4.0 may not be covered very well by these variables. Finally, our analysis refers to Industry 4.0-related digital divide at a specific point in time, the year 2016.

In this study, Industry 4.0-related digital divide has been determined by multivariate statistical techniques such as principal component analysis and multidimensional scaling analysis. Indicators related to big data, cloud computing, and radio frequency services were included in the analysis. The results of the principal component analysis have revealed that there are three dimensions of digital divide related to Industry 4.0. The findings obtained from this analysis show that the top performers in the first dimension related to big data are the Netherlands, Malta, Belgium, and the UK, respectively. Germany, the Netherlands, Austria, and Belgium have the best performance in terms of the second dimension. The countries (Finland, Croatia, Sweden, and Slovakia) in the last dimension that are represented by the IoT and CCS are different from the others. Therefore, the level of development of countries such as Croatia and Slovakia are lower than that of the EU average, whereas in countries such as Finland and Sweden it is higher. From this point, it can be said that considering the first and second dimensions, a relationship exists between the development levels of the countries and their Industry 4.0 performance; however, not for the last dimension. In other words, country rankings are based on the level of development in terms of the first and second dimensions. Similarly, the results of the multidimensional scaling analysis support the main findings of previous analyses. According to empirical results, Finland, the UK, and Germany are at a higher level of development regarding Industry 4.0. However, Cyprus, Bulgaria and Romania are among the countries below the union average. As a result, it can be said that our findings support that there is an Industry 4.0-related digital divide within the European Union member states.

One of the main priorities of the European Union is to bridge the digital divide within member states. For this, the European Commission has focused on the digital Agenda for Europe and Digital single Market Strategy and has provided a variety of funding programs such as the Connected Europe Facility (CEF), European Fund for Strategic Investments (EFSI), and Horizon 2020 to achieve the goals related to digital divide. In contrast, there are two important issues closely connected to the digital divide among member states in the 
agenda of the European Union: Industry 4.0 process and digital society. If the EU wants to achieve these goals, it should firstly focus on the existing differences among member states in terms of economic development. This is due to the fact that the EU consists of countries which have varying economic development, and many studies indicate that the level of economic development is positively related to Industry 4.0 and digital society indicators. Consequently, European institutions should develop different policies for countries that have different digital divide levels. At the same time, it should not be ignored that cultural and social differences, as well as economic development, are particularly reflected in computer and internet use.

\section{References}

Almada-Lobo, F. (2015), “The Industry 4.0 Revolution and the Future of Manufacturing Execution Systems (MES)", Journal of Innovation Management, 3(4), 16-21.

Atik, H. \& F. Ünlü (2017), "Science Performance of Turkey in $21^{\text {st }}$ Century: A Multivariate Statistical Comparison with the OECD Countries", in: H. Arapgiroğlu et al. (eds), Researches on Science and Art in $21^{\text {st }}$ Century Turkey, Ankara: Gece Publishing, 10301038.

Atik, H. \& F. Ünlü (2018), “Industry 4.0 and the European Union: An Empirical Analysis”, in: H. Arapgiroğlu et al. (eds), The Most Recent Studies in Science and Art, Ankara: Gece Publishing, 928-938.

Basl, J. (2016), "The Pilot Survey of Industry 4.0 Principles penetration in the Selected Czech and Polish Companies", Journal of Systems Integration, 7(4), 3-8.

Basl, J.P. (2017), "Study of Readiness of Czech Companies to Implement the Principles of Industry 4.0.", Management and Production Engineering Review, 8(2), 3-8.

Baunsgaard, V.V. \& S.R. Clegg (2015), "Innovation: A Critical Assessment of the Concept and Scope of Literature", in: Selen et al. (eds), The Handbook of Service Innovation, Springer: London, 5-25.

Bello-Orgaz, G. \& J.J. Jung \& D. Camacho (2016), "Societal Big Data: Recent Achievements and New Challenges", Information Fusion, 28, 45-59.

Bittighofer, D. \& M. Dust \& A. Irslinge \& M. Liebich \& L. Martin (2018), "State of Industry 4.0 across German Companies: A Pilot Study", 2018 IEEE International Conference on Engineering, Technology and Innovation (ICE/ITMC).

Borg, I. \& P.J.F. Groenen (2005), Modern Multidimensional Scaling: Theory and Applications, $2^{\text {nd }}$ ed., Springer: Germany.

Brettel, M. \& N. Friederichsen \& M. Keller \& M. Rosenberg (2014), "How Virtualisation, Decentralisation and Network Building Change the Manufacturing Landscape: An Industry 4.0 Perspective", International Journal of Information and Communication Engineering, 8(1), 37-44.

Cox, T.F. \& M.A.A. Cox (2001), Multidimensional Scaling, Chapman and Hall: New York.

Cruz-Jesus, F. \& M.R. Vicente \& F. Bacao \& T. Oliveira (2016), "The Education Related Digital Divide: An Analysis for the EU-28", Computers in Human Behaviour, 56, 72-82.

Cruz-Jesus, F. \& T. Oliveira \& F. Bacao (2012), "Digital Divide across the European Union", Information \& Management, 49(6), 278-291. 
Cuervo, M.R.V. \& A.J.L. Menéndez (2006), “A Multivariate Framework for the Analysis of the Digital Divide: Evidence for the European Union-15", Information\& Management, 43(6), 756-766.

De Leeuw, J. \& W. Heiser (1982), “Theory of Multidimensional Scaling”, in: P.R. Krishnaiah \& L.N. Kanal (eds), Handbook of Statistics, North-Holland Publishing Company: Netherlands, 285-316.

DeCoster, J. (1998), Overview of Factor Analysis, <http://www.stat-help.com/notes.html>, 26.06.2018.

Dewan, S. \& D. Ganley \& K.L. Kraemer (2005), “Across the Digital Divide: a Cross-Country Analysis of the Determinants of IT Penetration", Journal of the Association of Information Systems, 6(12), 298-337.

Dukić, B. \& S. Dugandžić \& S. Dukić (2017), "Conceptual CRM Application Database Model in the Function of Physical Products Distribution for Known Customer", $17^{\text {th }}$ International Scientific Conference Business Logistics in Modern Management, October 12-13 Osijek, Croatia.

European Parliament (2016), Industry 4.0. Brussels: European Union, Policy Department A, Economic and Scientific Policies, <http://www.europarl.europa.eu/studies>, 25.07.2018.

European Union (2016), Smarter, Greener, More inclusive? Indicators to Support the Europe 2020 Strategy, $1^{\text {st }}$ ed., European Union: Luxembourg.

Eurostat (2018), Digital Economy and Society Statistics, <https://ec.europa.eu/eurostat/web/digitaleconomy-and-society/data/database $>, 12.11 .2018$.

Giguere, G. (2006), "Collecting and Analyzing data in Multidimensional Scaling Experiments: A Guide for Psychologists using SPSS", Tutorials in Quantitative Methods for Psychology, 2(1), 26-37.

Gilchrist, A. (2016), Industry 4.0: The Industrial Internet of Things, Apress, Thailand.

Greengard, S. (2015), The Internet of Things, The MIT Press Essential Knowledge Series, MIT Press: USA.

Haddara, M. \& A. Elregal (2015), "The Readiness of ERP Systems for the Factory of the Future", Procedia Computer Science, 64, 721-728.

Hair, J. \& R. Anderson \& R. Tatham \& W. Black (1995), Multivariate Data Analysis: With Readings, Prentice Hall International: London, UK.

Hashem, A.B.T. \& I. Yaqoop \& N.B. Anvar \& S. Mokhtar \& A. Gani \& U.S. Khan (2015), "The Rise of 'Big Data' on Cloud Computing: Review and Open Research Issues", Information Systems, 47, 98-115.

INFOSYS (2015), Industry 4.0: The State of the Nations, $<\mathrm{http}: / / \mathrm{www}$.experienceinfosys.com/industry-4-0>, 15.06.2018.

Jacoby, W.G. \& D.J. Ciuk (2014), Multidimensional Scaling: An Introduction, $<$ http://polisci.msu.edu/jacoby/research/scaling/intromds/JacobyCiuk, \%20MDS, \%20V2, 2010-29-14.pdf>, 17.06.2018.

Jaworska, N. \& A.C. Anastasova (2009), “A Review of Multidimensional Scaling (MDS) and its Utility in Various Psychological Domains", Tutorials in Quantitative Methods for Psychology, 5(1), 1-10. 
Jia, X. \& Q. Feng \& T. Fan \& Q. Lei (2012), "RFID Technology and Its applications in Internet of Things (IoT)", $2^{\text {nd }}$ International Conference on Consumer Electronics, Communications and Networks, 21-23 April, 2012.

Jin, X. \& B.W. Wah \& X. Cheng \& Y. Wang (2015), "Significance and Challenges of Big Data Research", Big Data Research, 2, 59-64.

Kagermann, H. \& W. Wahlster (2013), "Securing the Future of German manufacturing Industry: Recommendations for Implementing the Strategic Initiative INDUSTRIE 4.0", Working Group, Acatech- National Academy of Science and Engineering, Germany, Final Report of the Industrie 4.0.

Kruskal, J.B. (1964), "Multidimensional Scaling by Optimizing Goodness of Fit to a Nonmetric Hypothesis", Psychometrika, 29, 1-27.

Kuruczleki, E. \& A. Pelle \& R. Laczi \& B. Fekete (2016), "The Readiness of the European Union to Embrace the Fourth Industrial Revolution", Management, 11(4), 327-347.

Lee, I. \& K. Lee (2015), “The Internet of Things (IoT): Applications, Investments, and Challenges for Enterprises", Business Horizons, 58(4), 431-440.

Lom, M. \& O. Pribly \& M. Svitek (2016), "Industry 4.0 as a Part of Smart Cities”, Smart Cities Symposium Prague.

Manly, B.F.J. (1986), Multivariate Statistical Methods: A Primer, Arrowsmith: Bristol.

Marston, S. \& Z. Li \& S. Bandyopadhyay \& J. Zhang \& A. Ghalsasi (2011), "Cloud Computing- The Business Perspective", Decision Suppoer Ssytems, 51, 176-189.

McKinsey (2011), "Big Data: The Next Frontier for Innovation, Competition, Productivity", in: McKinsey Global Institute Report.

Nakip, M. (2006), Pazarlama Araştırmaları Teknikler ve (SPSS Destekli) Uygulamalar, $2^{\text {nd }}$ ed., Seçkin Yayıncılık: Ankara.

Nick, G. \& F. Pongrácz (2016), "How to Measure Industry 4.0 Readiness of Cities”, International Scientific Journal, 1(2), 136-141.

OECD (2001), Understanding the Digital Divide, $1^{\text {st }}$ ed.; OECD: Paris.

Platform Industrie 4.0. (2013), Recommendations for Implementing the Strategic Initiative INDUSTRIE 4.0.

Roblek, V. \& M. Meško \& A. Krapež (2016), “A Complex View of Industry 4.0”, Sagepub, AprilJune, 1-11.

Roland Berger (2014), Think Act: Coo Insights- Industry 4.0, <http://www.rolandberger.com/media/pdf/Roland_Berger_TAM_COOInsights_E_20150 1/3.PDF>, 28.06.2015.

Roland Berger (2015), Industry 4.0: The Role of Switzerland within a European Manufacturing Revolution, <https://www.rolandberger.com/en/Publications/Industry-4.0-The-roleofSwitzerland.html>, 17.06.2018.

Saeed, N. \& H. Nam \& M.I.U. Hag \& D.M.S. Bahtti (2018), “A Survey on Multidimensional Scaling”, ACM Computing Surveys, 1(1), 1-26.

Schlechtendahl, J. \& M. Keinert \& F. Kretschmer \& A. Lechler \& A. Verl (2015), "Making Existing Production System Industry 4.0 -Ready", Production Engineering, 9(1), 143-148.

Sharma, S. (1996), Applied Multivariate Techniques, John Wiley \& Sons, Inc.: New York. 
Stock, T. \& G. Seliger (2016), “Opportunities of Sustainable Manufacturing in Industry 4.0”, $13^{\text {th }}$ Global Conference on Sustainable Manufacturing - Decoupling Growth from Resource Use, Procedia CIRP 40, 536-541.

Stojkić, Z. \& I. Veža \& I. Bošnjak (2016), “A Concept of Information System Implementation (CRM and ERP) within Industry 4.0", Proceedings of the 26th DAAAM International Symposium, 912-919.

Tabachnick, B.G. \& L.S. Fidell (2015), Using Multivariate Statistics, Pearson: UK.

Taherdoost, H. \& S. Sahibuddin \& N. Jalaliyoon (2014), "Exploratory Factor Analysis; Concepts and Theory", Advances in Applied and Pure Mathematics, 375-382.

Tavakol, M. \& R. Dennick (2011), “Making Sense of Cronbach's Alpha”, International Journal of Medical Education, 53-55.

Tryfos, P. (1997), Methods for Business Analysis and Forecasting: Text \& Cases, Wiley.

Tucker, L.R. \& R.C. MacCallum (1997), "Exploratory Factor Analysis”, Unpublished Manuscript, Ohio State University, Columbus.

Verma, J.P. (2013), Data Analysis in Management with SPSS Software, Springer: India.

Vicente, M.R. \& A.J. Lopez (2011), “Assessing the Regional Digital Divide across the European Union-27”, Telecommunications Policy, 35, 220-237.

Weinberg, S.L. (1991), “An Introduction to Multidimensional Scaling”, Measurement and Evaluation in Counselling and Development, 24, 12-36.

Wickelmaier, F. (2003), “An Introduction to MDS”, Unpublished Manuscript, Sound Quality Research Unit at Aalborg University.

Xu, L.D. \& L. Duan (2019), "Big Data for Cyber Physical Systems in Industry 4.0: A Survey", Enterprise Information Systems, 13(2), 148-169.

Yong, A.G. \& S. Pearce (2013), “A Beginner's Guide to Factor Analysis: Focusing on Exploratory Factor Analysis”, Tutorials in Quantitative Methods for Psychology, 9(2), 79-94. 